\title{
Public participation in public private partnership projects - the way forward
}

\author{
S. T. Ng, J. M. W. Wong \& K. K. W. Wong \\ Department of Civil Engineering, The University of Hong Kong, \\ Hong Kong
}

\begin{abstract}
Delivering public facilities and services through the public private partnerships approach has become increasingly popular. Unlike those public schemes where the government is responsible for the planning tasks, the private investors should formulate innovative solutions to satisfy the requirements and expectations of the society. Therefore, meeting the triple bottom line of people, planet and profit becomes a major challenge of the private investors, especially when the scheme could last for years and the impacts to the society, if any, may be very deep-rooted. Until now, little attention has been attributed to uplift the process of public participation in public private partnership projects, and there is a need to examine what should be done to ensure the interests of the community are catered for without compromising on the financial return. In this paper, the current practice of public participation in public private partnership projects is unveiled. Based on the findings of interviews conducted with relevant experts in Hong Kong, recommendations are made to rationalise the public participation process for public private partnerships. The findings of this paper would serve as a basis for the government of different countries to formulate policies to balance the interests of the private investors and the community in public private partnership projects.
\end{abstract}

Keywords: public private partnerships, public engagement, social concerns, construction projects.

\section{Introduction}

Public private partnerships (PPP) offer a promising project delivery alternative by capitalising on the financial, creative, managerial and commercial strengths of the private sector for facilities or services provision that would otherwise be 
ineffective or even impossible under a diminishing public capital expenditure regime [1-3]. Getting the private sector involved in the provision of public facilities and services could not only increase market competition and reduce reliance on the government [4], but it would also help stimulate the economy and create jobs [5]. The consequence is an improvement in productivity, service quality, work efficiency and cost effectiveness. Therefore, PPP has been widely used for the delivery of social facilities and services.

PPP would only be justified if such an approach could provide greater valuefor-money to the public sector and is financially viable to the private investors. However, the best value may not necessarily be realised in every PPP project, as divergence in interests exists among the government, private investors and the general public [6,7]. The public sector is subject to a higher risk in a PPP project [8], as there is a chance of losing public control over the private sector on service quality $[9,10]$. Yet, the genuine concern of any PPP projects is the problem of accountability [11-13], including the problem of corruption and possible accusation of the transfer of business benefits [9].

Conflict of interests also arises when the pursuit for social benefits does not concur with the commercial returns and public savings [6, 14]. Pearson [15] believed that a PPP scheme would appeal to the community if it could result in an earlier availability of services, lower cost and better services quality. Other concerns of the general public include the reliability of service, level of charge, job opportunities, service failure, and so on $[7,8,16,17]$. A successful PPP scheme is one that can satisfy the interests of all the three key parties.

Currently, a mechanism known as the public sector comparator (PSC) is adopted by many countries including the United Kingdom, Australia and Hong Kong to establish whether PPP is a more attractive project delivery option than being procured in traditional ways by the government. Nonetheless, the evaluation in PSC is hinged on the financial merits of PPP schemes [11, 13]. This makes the outcomes at times rather 'artificial' and 'biased' [18]. Whitefield [9] argued that PSC and other pure quantitative evaluation approaches may be opened to manipulation should the costs and benefits of a PPP option be distorted.

To increase the chance of success, it is necessary to appreciate the concerns of the society being affected by or interested in the PPP scheme. In this paper, the current practice of how social concerns are incorporated in the PPP process is first examined through a literature review. The concerns of PPP stakeholders are then identified. Finally, recommendations are put forward to improve the PPP process by considering the social aspects during each stage of the PPP process.

\section{PPP guidelines}

Various PPP guidelines in advanced countries have been examined to unveil the current practice of evaluating a PPP project. In the UK, the London Government has issued a guidance note to assist decision-makers on how to assess the valuefor-money of PPP projects [3]. The guidance note emphasises that the option of PPP is only recommended after a robust assessment of all available options in 
each set of circumstances [19]. It also suggests decision-makers to carry out value-for-money assessment at various stages of the project including at the early investment programme level, project level and procurement level. Evaluation procedures mainly involve market sounding which aims to determine the level of market interest; affordability test to ensure that the project is affordable by the government; qualitative assessment which involves the construction of public sector comparator; and qualitative assessment which addresses the different aspects of the PPP option in terms of viability, desirability and achievability. A detailed guideline on how to construct a public sector comparator has also been issued by the government [20].

The Ireland Government published a guidance note for PPP assessment in April 2000. This guidance note aims to assist decision-makers of the public sector to assess the potential of PPP to deliver improved value-for-money compared with traditional procurement at the 'option appraisal stage' [21]. The key elements in the PPP assessment process include: (i) initial output specification which includes definition of the required level of services; (ii) value-for-money assessment which involves identification of qualitative evaluation factors; (iii) preliminary risk assessment which includes the identification, quantification and allocation of risks; (iv) bankability assessment which includes the establishment of financing issues; (v) legal viability assessment which includes assessment of the legal ability of the contracting authority to enter into a PPP contract as well as other legal implications related to existing employees and assets; (vi) PPP option selection which involves the selection of the form and scope of PPP that offers best value-for-money; (vii) final value-for-money assessment which involves the identification of evaluation parameters and preparation of a financial comparator; and (viii) indicative implementation plan which involves planning of the organisational management structure and timetable for the activities in project procurement.

In Canada, the Ministry of Municipal Affairs issued a PPP guide in May 1999 to assist local governments to evaluate various forms of service delivery and to establish the PPP arrangements [10]. This guide provides a list of factors that should be considered by decision makers when deciding whether to partner with the private sector. The various factors include: (i) the experience of local government; (ii) opportunity for innovation; (iii) support from users; (iv) existence of regulatory or legislative constraints; (v) quality of service output; and (vi) opportunities to foster economic development. The Industry Canada also published a PPP Canadian guide for practitioners which provides a more detailed discussion on the evaluation criteria that should be considered before pursing the PPP approach [22]. Six major criteria were identified, and they include (i) financial criteria - which refers to cost effectiveness calculation which can be done by CBA or PSC; (ii) technical criteria - which includes considerations about appropriate technical specification and mechanism for monitoring private sector performance; (iii) operational criteria - which includes the identification and articulation of operation and maintenance standards; (iv) acceptability which is about the acceptance, support and commitment from the political parties, community and existing staff; (v) implementation - which is about the 
opportunity for competition among perspective private partners, the legislative, regulatory and policy constraints, as well as the existence of in-house strong project team; and (vi) timing - which is about the adequacy of timelines to develop the operating specifications. Industry Canada has also issued a comprehensive guide for the use and construction of PSC [23].

In Australia, according to APCC [24], the feasibility of a potential PPP project is determined from the cost comparison between public sector comparator and PPP bids together with some non-financial considerations which are however not specified. The guidelines issued by the South Australian Government also emphasise on the application of public sector comparator for PPP feasibility evaluation while again no qualitative factors are mentioned [25]. However, the New South Wales Government and Victorian Government specifically include a 'public interest test' in the feasibility evaluation to assess PPP projects against public interest criteria before the project is put to market [26]. Those public interest criteria include project effectiveness, accountability and transparency, public access and equity, consumer rights, security, and privacy.

In South Africa, a guide known as "Guidelines for undertaking a feasibility study for PPP projects" was issued by the National Treasury in 2001. It suggests that the feasibility study of a PPP project should contain the following sections: (i) needs-assessment; (ii) output specification; (iii) options analysis; (iv) PSC construction; (v) demonstration of affordability; and (vi) preparation of a benchmark for value-for-money [27]. While the above steps mainly involve the financial considerations of PPP, the feasibility guide also reminds decisionmakers the importance of the identification of qualitative factors, which were however not discussed in detail. In the PPP manual issued by the National Treasury in 2004, the authority has revised the recommended stages of PPP feasibility study to include the consideration of project due diligence before the construction of PSC and other economic valuations so as to address other qualitative factors like legal and socio-economic issues at early stage [28].

In Hong Kong, the Efficiency Unit of the HKSAR Government has issued an "Introductory Guide to Public Private Partnerships" in June 2003 discussing the various issues of PPP, including its advantages over conventional approaches, the construction of public sector comparator, selection of right private partner, financial and staffing issues, etc. A guideline published by the Efficiency Unit [29] in 2008 recommends engaging the public as soon as possible with on-going dialogues throughout the preparatory and implementation phases. However, the details in which public engagement should be carried out in each strategic stage of a PPP project are still lacking in this guide. The government departments are, therefore, free to conduct feasibility studies for their potential projects according to the department's objectives.

\section{Perception of stakeholders}

With a desire to improve the practice of PPP evaluation and to increase the success of PPP projects, semi-structured interviews were conducted with experts 
with significant knowledge and experience in PPP schemes and/or public engagement. Finally, 15 interviews were completed with representatives of the government, private firms, district council and professional institutions.

The majority of interviewees believed that it is necessary to improve the public engagement process in a PPP scheme. Nearly all of the interviewees expressed that public engagement shall be conducted at an early stage of a PPP scheme. They believed the government needed to do a better job in communicating with the public and improve on the packaging and presentation of the development plans so that the benefits of the project can be fully conveyed to the public, making it easier to gain social acceptance.

There were opposing views amongst the interviewees on the topic of how public opinions should be incorporated into projects. One perspective was that public opinions should only be used for references and it is up to decision makers to decide after taking into account other aspects such as technical, economic, environmental, social and political constraints. The other perspective was that the public should have the ultimate decision since they are the ones who will be directly affected by the project. Yet, interviewees generally agreed that it is difficult to analyse the intangible benefits.

It was widely agreed upon that the best way to safeguard stakeholders' (and in particular public) interest is to have contracts and tendering selection processes structured in such a way that criteria for meeting social objectives are clearly stated. To retain interest from the private sector, incentives should also be incorporated into contracts when social benefits goals are met or exceeded. It was also suggested that a wide range of channels should be offered to the public for communicating their feedback throughout the entire process.

\section{The way forward}

Based on the interview findings, it seems imperative to improve the public engagement process. While the process of PPP has been widely publicised and adopted, it is sensible to follow the steps of PPP as stipulated in the guideline instead. The "Introductory Guide to Public Private Partnerships" prepared by the Efficiency Unit of the HKSAR Government provides a clear definition about each stage of the PPP process, and it would be useful to try to incorporate the public engagement activities in each stage of the PPP process.

According to the guideline, a PPP scheme shall be divided into eight stages: (i) mobilisation and development of a business case; (ii) funding; (iii) technical assessment, consultation and land requirements; (iv) expression of interest exercise; (v) policy and funding approvals; (vi) procurement and selection; (vii) service commencement; and (viii) payment and contract management. Table 1 highlights the public engagement activities at each of the eight stages of a PPP project.

The concerns of the society should be identified as early as possible, and this can be achieved through various channels, e.g. pre-consultation meetings with major stakeholders and professional institutions, public forums with the entire 
Table 1: $\quad$ Possible engagement activities in a PPP project.

\begin{tabular}{|c|c|c|c|}
\hline Stage & PPP Activity & Engagement Activity & Purpose \\
\hline \multirow[t]{2}{*}{1} & \multirow[t]{2}{*}{$\begin{array}{l}\text { Mobilisation and } \\
\text { development of } \\
\text { business case }\end{array}$} & $\begin{array}{l}\text { Pre-consult major } \\
\text { stakeholders and } \\
\text { professional institutions }\end{array}$ & $\begin{array}{l}\text { To predict the public } \\
\text { concerns and estimate the } \\
\text { technical and financial } \\
\text { feasibility }\end{array}$ \\
\hline & & $\begin{array}{l}\text { Public consultation on } \\
\text { possible options }\end{array}$ & $\begin{array}{l}\text { To generate innovative } \\
\text { ideas }\end{array}$ \\
\hline 2 & Funding & $\begin{array}{l}\text { Gather opinions about } \\
\text { the social concerns and } \\
\text { their potential impacts }\end{array}$ & $\begin{array}{l}\text { To include the identified } \\
\text { social impacts in the public } \\
\text { sector comparators }\end{array}$ \\
\hline \multirow[t]{2}{*}{3} & \multirow{2}{*}{$\begin{array}{l}\text { Technical } \\
\text { assessment, } \\
\text { consultation and } \\
\text { land requirements }\end{array}$} & $\begin{array}{l}\text { Seek consensus with the } \\
\text { general public on the } \\
\text { overall vision }\end{array}$ & $\begin{array}{l}\text { To agree on the most } \\
\text { feasible and beneficial } \\
\text { option }\end{array}$ \\
\hline & & $\begin{array}{l}\text { Engage the general } \\
\text { public in developing the } \\
\text { conceptual scheme / plan }\end{array}$ & $\begin{array}{l}\text { To work out some } \\
\text { preliminary details of the } \\
\text { scheme }\end{array}$ \\
\hline 4 & $\begin{array}{l}\text { Expression of } \\
\text { interest }\end{array}$ & $\begin{array}{l}\text { Collect feedback about } \\
\text { the possible accusation } \\
\text { of transfer of interest }\end{array}$ & $\begin{array}{l}\text { To ensure there is a } \\
\text { balance between social and } \\
\text { commercial interests }\end{array}$ \\
\hline 5 & $\begin{array}{l}\text { Policy and funding } \\
\text { approval }\end{array}$ & $\begin{array}{l}\text { Continue to monitor the } \\
\text { perception of the general } \\
\text { public }\end{array}$ & $\begin{array}{l}\text { To establish appropriate } \\
\text { policies to ensure social } \\
\text { interests are duly taken } \\
\text { care of }\end{array}$ \\
\hline 6 & $\begin{array}{l}\text { Procurement and } \\
\text { selection }\end{array}$ & $\begin{array}{l}\text { Professional groups and } \\
\text { watchdogs to monitor the } \\
\text { negotiate process }\end{array}$ & $\begin{array}{l}\text { To ensure the concession } \\
\text { items are to the best } \\
\text { interest of the society }\end{array}$ \\
\hline 7 & $\begin{array}{l}\text { Service } \\
\text { commencement }\end{array}$ & $\begin{array}{l}\text { General public to } \\
\text { monitor the services } \\
\text { being provided }\end{array}$ & $\begin{array}{l}\text { To guarantee the services } \\
\text { provided are up to the } \\
\text { expectation of the society }\end{array}$ \\
\hline 8 & $\begin{array}{l}\text { Payment and } \\
\text { contract } \\
\text { arrangement }\end{array}$ & $\begin{array}{l}\text { Collect complaints and } \\
\text { feedback from the users }\end{array}$ & $\begin{array}{l}\text { To impose sanctions and } \\
\text { penalties to non- } \\
\text { performing service } \\
\text { providers }\end{array}$ \\
\hline
\end{tabular}

society, focus group meetings with the affected groups, and interactive discussions with various sectors. These would help the government generating innovative ideas and establishing a checklist of social concerns or even a wish list for the scheme before inviting any private investors to express their interests and submitting a proposal.

As PPP scheme would normally take time to plan and negotiate, the concerns of the citizens could have changed over time. It is therefore necessary to continue monitoring the perception of the community at the funding approval and procurement stages. The government should strive to balance the interests of the society and private investor if necessary and consider whether it is still worth pursuing PPP any more. Professional institutions and watchdogs should be invited to monitor the development of the proposals and the negotiation process 
to ensure the interests of the public by and large as identified at the preceding stages are duly considered before the scheme is awarded.

There are examples where the facility and service providers failed to fulfil their service pledge. It is, therefore, important to involve the general public at the operation stage. Channels should be provided to the end-users, affected residents and pressure groups to make complaints or provide feedbacks to the government such that appropriate sanctions and penalties can be imposed to those nonperforming service providers.

\section{Conclusions}

While PPP is an effective mechanism to ensure essential social facilities and services are provided under a tight public budget, the success of these projects depends not only on the financial viability of the scheme, but also more importantly on whether the scheme meets the expectations of the society. Unfortunately, the current practice of PPP evaluation focuses excessively on the value-for-money from a financial perspective. To improve the chance of success, the value of a PPP scheme should be built on social value and satisfaction instead.

Currently, there is no systematic mechanism governing how social concerns should be captured from the society at different stages of a PPP project. It is imperative to devise a framework to guide the public engagement process so that different levels of the society can take part in a project which is meant to serve their needs. In this paper, a list of public engagement activities has been put forwarded for each of the PPP stages. Further research should be conducted to establish whether those activities are appropriate and adequate. Moreover, the perceptions of the society could be rather subjective, and it is necessary to develop a more transparent method to evaluate the social impacts in future.

\section{Acknowledgement}

The authors would like to thank the Research Grants Council of the Government of Hong Kong Special Administrative Region for financially supporting this study through the Public Policy Research Scheme (Grant No.: 7010-PPR-4).

\section{References}

[1] City of Seattle, Effective Public Private Partnership, Performance Perspective, Report \#8, City of Seattle: Seattle, 1999.

[2] Grimsey, D. \& Lewis, M.K., Evaluating the risks of public private partnerships for infrastructure projects, International Journal of Project Management, 20(2), pp. 107-118, 2002.

[3] HM Treasury, Value for Money Assessment Guidance, HMSO: London, 2004. 
[4] Zhang X., Financial viability analysis and capital structure optimization in privatised public infrastructure projects, Journal of Construction Engineering and Management, ASCE, 131(6), pp. 656-668, 2005.

[5] Bertig, E. O'Connor, J., Stambor, P., Steers, L. \& Wall, I., Public-Private Partnerships in Seattle, League of Women Voters of Seattle: Seattle, 2000.

[6] Reijniers, J.J.A.M., Organisation of public-private partnership projects, the timely prevention of pitfalls, International Journal of Project Management, 12(3), pp. 137-142, 1994.

[7] Akintoye, A., Hardcastle, C., Beck, M., Chinyio, E. \& Asenova, D., Achieving best value in private finance initiative project procurement, Construction Management and Economics, 21(5), pp. 461-470, 2003.

[8] Li, B. Akintoyle, A., Edwards, P.J. \& Hardcastle, C., Perceptions of positive and negative factors influencing the attractiveness of PPP/PFI procurement for construction projects in the UK, Engineering, Construction and Architectural Management, 12(2), pp. 125-148, 2005.

[9] Whitefield. D, Public Services or Corporate Welfare: Rethinking the Nation State in the Global Economy, Pluto Press: London, 2001.

[10] MOMA, Public Private Partnership - A Guide for Local Government, Ministry of Municipal Affairs: British Columbia, Canada, 1999.

[11] Berg, S.V., Pollitt, M.G. \& Tsuji, M., Private Initiatives in Infrastructure: Priorities, Incentives and Performance, Edward Elgar: Cheltenham, Northampton, UK, 2002.

[12] Freeman, M., Critical Choices: The Debate over Public-Private Partnerships and What is Means for American's Future, The National Council for Public-Private Partnerships: Washington D.C., 2003.

[13] Efficiency Unit, Serving the Community by Using the Private Sector - An Introductory Guide to Public Private Partnerships (PPPs), The Government of HKSAR: Hong Kong, 2003.

[14] Broadbent, J. \& Laughlin, R., Public private partnership: an introduction, Accounting, Auditing \& Accountability Journal, 16(3), pp. 332-341, 2003.

[15] Pearson, M., Opportunities and obstacles for wider adoption of PPP models in Hong Kong, Proceedings: Public Private Partnerships - Opportunities and Challenges, Creative Consulting Group Inc. Ltd., Hong Kong, 2005.

[16] Flanagan, J.L., Private/public partnership: a balancing act, Public Works, ProQuest Science Journals, 128(10), pp. 49-52, 1997.

[17] Sahooly, A., Public-private partnership in the water supply and sanitation sector: the experience of the Republic of Yemen, Water Resources Development, 19(2), pp. 139-152, 2003.

[18] Sussex, J., The Economics of the Private Finance Initiative in the NHS, Office for Health Economics: London, 2001.

[19] HMSO, Local Government Act, HMSO: London, 1998.

[20] Treasury Taskforce, How to Appoint and Work with a Preferred Bidder, Technical Note No. 4, Treasury Taskforce - Private Finance, HMSO: London, 1999. 
[21] DOE, Public Private Partnership Assessment, Public Private Partnership Guidance Note 4, Department of the Environment and Local Government: Ireland, 2000.

[22] Industry Canada, Public-Private Partnerships: A Canadian Guide, A Guide for Practitioners of Public-Private Partnerships (P3s) which Represents the Best Experiences and Practices of those Currently Engaged in P3 Activity, Industry Canada: Canada, 2001.

[23] Industry Canada, The Public Sector Comparator - A Canadian Best Practices Guide, Services Industries Branch, Industry Canada: Canada, 2003.

[24] APCC, Discussion Paper: Key Issues in Procurement through PPPs, Australian Procurement and Construction Council: Australia, 2002.

[25] South Australian Government, Private Sector Participation in the Provision of Public Services - Guidelines for the Public Sector, Department of Treasury and Finance, South Australian Government: Adelaide, 2002.

[26] Webb, R. \& Pulle, B., Public Private Partnerships: An Introduction, Research Paper No. 1, 2002-2003, Economics, Commerce and Industrial Relations Groups, available at http://www.aph.gov.au/library/pubs/rp/200203/03RP01.htm, 2002.

[27] National Treasury, Feasibility Guidelines, Guidelines for Undertaking a Feasibility Study for PPP Projects, National Treasury PPP Manual, version I, National Treasury: South Africa, 2001.

[28] National Treasury, PPP Manual - Module 4: PPP Feasibility Study, National Treasury PPP Practice Note No. 5, PPP Unit, National Treasury: South Africa, 2004.

[29] Efficiency Unit, An Introductory Guide to Public Private Partnerships, Efficiency Unit, Hong Kong SAR Government: Hong Kong, 2008. 